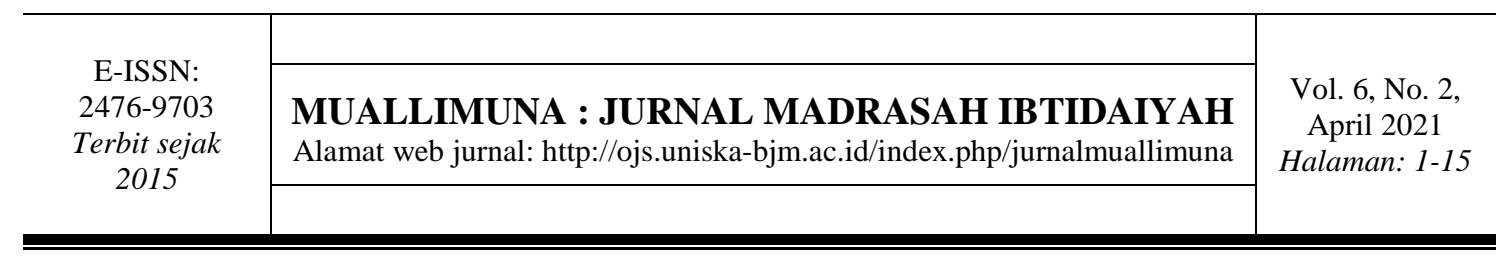

\title{
PENGEMBANGAN MEDIA WAYANG BERBASIS TOKOH PAHLAWAN NASIONAL UNTUK KELAS IV SEKOLAH DASAR
}

\author{
Arya Setya Nugroho ${ }^{1}$, Wahyuni ${ }^{2}$ \\ ${ }^{12}$ Program Studi Pendidikan Guru Sekolah Dasar, \\ Universitas Muhammadiyah Gresik \\ ${ }^{1}$ aryasetya@umg.ac.id, ${ }^{2}$ wahyuniyunayuni@gmail.com
}

\begin{abstract}
Abstrak: Pengembangan wayang ini dimaksudkan untuk pemenuhan ketersidaan media yang memberikan kemudahan dalam pengelolaan proses belajar mengajar. Model metode penelitian ini merupakan model R\&D (Research and Development), namun hanya menggunakan lima tahapan ialah potensi dan masalah, pengumpulan data, desain produk, validasi desain serta revisi desain. Hal tersebut disesuaikan dengan kebutuhan penelitian dan kondisi pandemi saat ini. Hasil valid serta layak diperoleh dari validasi media serta materi dari pakar validator kemudian dapat diaplikasikan dalam kegiatan pembelajaran. Hasil validitas atas pakar materi 1 diperoleh nilai 20 atau $80 \%$ dan ahli materi 2 memperoleh skor 22 atau 88\%, sedangkan hasil validitas dari pakar media 1 mendapatkan nilai 43 atau 91\% dan validasi pakar media 2 memperoleh 41 atau 95,5\%. Pengembangan wayang tersebut diharapkan mampu memenuhi perangkat pembelajaran salah satu nya media sebagai penunjang keterlaksanaan proses belajar mengajar.
\end{abstract}

Kata Kunci: media, wayang, tokoh, pahlawan

\section{DEVELOPING WAYANG BASED NATIONAL HEROES FOR THE $4^{\text {th }}$ GRADE ELEMENTARY SCHOOL'S TEACHING MEDIA}

Abstract: The development of puppets is intended to fulfill the availability of media which provides convenience in managing the teaching and learning process. The research method model used is the $R \& D$ (Research and Development) model, but it only uses five stages, namely potential and problems, data collection, product design, design validation and design revision. This is adjusted to the needs of research and the current pandemic conditions. The results of media validation by media and material expert validators obtained valid results and were feasible to be applied in the teaching and learning process. The results of the validity of the material expert 1 obtained a score of 20 or $80 \%$ and the material expert 2 obtained a score of 22 or $88 \%$, while the results of the validity of the media expert 1 got a value of 43 or $91 \%$ and the validation of the media expert 2 got 41 or $95.5 \%$. The development of puppets is expected to be able to fulfill learning tools, one of which is the media to support the implementation of the teaching and learning process.

Keywords: media, wayang, character, heroes

\section{PENDAHULUAN}

Media pembelajaran merupakan suatu alat yang bisa dimanfaatkan untuk membantu memudahkan kegiatan belejar mengajar yang akan dilakukan pendidik di kelas. Membuat media pembelajaran merupakan salah satu bentuk keterampilan seorang 
guru. Dengan adanya media, penyampaian materi lebih interaktif, proses belajar mengajar lebih efektif, suasana pembelajaran lebih menyenangkan dan menarik (Yuniati et al., 2011). Media pembelajaran bisa menyampaikan pesan, menjadi alat perangsang ide, tindakan, juga minat peserta didik selanjutnya untuk kepentingan peserta didik sebagai acuan dalam pembelajaran (Rustad et al., 2012). Media bisa dimanfaatkan sebagai alat untuk memberikan materi pembelajaran pada peserta didik supaya lebih mudah menguasai penjelasan pendidik. Dengan media dapat menambah dan mengembangkan pengetahuan yang dimiliki menjadi bermakna (Awalia et al., 2019). Seperti yang diindikasikan oleh Kemp dan Dayton, ada keuntungan dari media pembelajaran, yaitu khusus untuk membuat ulang materi pembelajaran, membuat instruksi dan latihan pembelajaran benar-benar menarik, membuat ukuran mendidik dan belajar yang cerdas, menghadapi peluang ideal untuk menyampaikan materi oleh instruktur semua lebih hati-hati, meningkatkan karakter belajar siswa, pelaksanaan latihan pembelajaran harus dapat dilakukan dimana saja, dan mencetak guru yang lebih profesional (Sani, 2019). Selain itu media juga berperan untuk alat bantu pada pelaksanaan kegiatan pembelajaran (Masykur et al., 2017).

Media pembelajaran memiliki kapasitas yang signifikan untuk mewujudkan ukuran pembelajaran (Nurrita, 2018). Media berperan dalam mempresentaasikan objek yang berukuran besar ke dalam kelas pembelajaran, seperti benda langit; menjadikan besar suatu yang sulit untuk dilihat dengan mata, sebagaimana sel darah atau molekul bakteri sejenisnya; mempercepat proses gerakan yang lambat, dengan demikian dapat dilihat pada waktu yang cepat, seperti tahapan pertumbuhan daun; menjadikan lambat gerakan yang cepat, seperti gerakan baling pesawat; menjadikan sederhana objek yang rumit; menjadikan jelas bunyi yang lemah, dengan demikian bisa didengar oleh telinga (Sani, 2019). Tersedianya media pembelajaran harapannya materi tersampaikan ke dalam kegiatan pembelajaran dapat lebih mudah diaplikasikan, dianalogikan, serta penyelesaian permasalahan lebih nyata dan bermakna (Agustina \& Suprianto, 2018). Media juga mendor ong kinerja kepala sekolah dalam mengelola kebijakan proses pembelajaran melalui program pengembangan media belajar supaya kegiatan belajar mengajar menjadi lebih efisien (Triyanto et al., 2013).

Penerapan media yang belum maksimal mengakibatkan permasalahan dalam pembelajaran. Berdasar hasil wawancara bersama ibu Innama, S.Pd. wali kelas IV UPT SD Negeri 40 Gresik ditemukan permasalahan yaitu pemahaman materi tokoh pahlawan nasional pada peserta didik masih minim dikarenakan konsep materi yang sulit dipahami peserta didik terbukti dari kemampuan menarasikan tentang tokoh pahlawan hanya mengetahui nama tokoh belum mengetahui sejarah, peran tokoh dalam perjuangan, dan konsep tentang tokoh yang diberikan oleh guru; kurangnya ketertarikan peserta didik terhadap materi tokoh pahlawan nasional terbukti dari tingkat konsentrasi peserta didik hanya sepuluh sampai lima belas menit awal kegiatan pembelajaran; media pembelajaran yang digunakan di kelas IV masih sederhana yaitu gambar tokoh pahlawan nasional. Dalam penelitian ini peneliti bermaksud memasukkan konsep tokoh pahlawan nasional kedalam konsep wayang, agar peserta lebih tertarik dan berperan serta pada pembelajaran di kelas. Penerapan media wayang dapat meningkatkan keaktifan belajar dan minat belajar (Mukholifah et al., 2020). Wayang ialah boneka tiruan manusia berasal dari ukiran kulit atau kayu serta bahan lain yang digunakan dalam pertunjukkan drama tradisional meliputi daerah Bali, Jawa, Sunda, serta daerah lainnya, umumnya yang memainkan wayang disebut dalang (Yasasusastra, 2011). Kesenian wayang sebagai alat komunikasi yang berfungsi sebagai interaksi dan 
mengembangkan komunikasi peserta didik (Ahlcrona, 2012). Media wayang tentang tokoh pahlawan nasional yang akan dibuat oleh peneliti untuk mengenalkan tokoh pahlawan dengan peserta didik, dan untuk menyambut peserta didik yang dinamis dalam interaksi pembelajaran. Penggunaan media pintar untuk peserta didik mampu meningkatkan keterlibatan belajar bagi peserta didik (Gweon et al., 2018).

Penelitian ini bermaksud akan mengembangkan media wayang berbasis tokoh pahlawan nasional untuk kelas IV UPT SD Negeri 40 Gresik, mengetahui validitas media wayang berbasis tokoh pahlawan. Dengan adanya hal itu maka peneliti terinspirasi untuk mengembangkan media wayang berbasis tokoh pahlawan nasional. Tokoh pahlawan nasional merupakan sosok yang rela berkorban untuk berjuang dan mengabdikan diri kepada bangsa dan negara Indonesia, dengan adanya media ini peserta didik dapat mengetahui sosok tokoh pahlawan nasional dan mengetahui peran mereka terhadap masyarakatnya waktu dulu sampai saat ini. Wayang sebagai hasil budaya masyarakat sejak sebelum Islam masuk di Indonesia (Marsaid, 2016). Peserta didik belajar wayang berarti juga belajar sejarah sekaligus perseptif masing-masing tokoh wayang tersebut. Tokoh pahlawan yang dipilih oleh peneliti adalah Sultan Hasanuddin dari Kerajaan Gowa, Makassar, Sulawesi Selatan dan Sultan Agung Hanyokrokusumodari Kerajaan Mataram Islam, Jawa Tengah, karena disesuaikan dengan kompetensi dasar yang ada. Selain itu pertimbangan peneliti terhadap keterbatasan waktu dan keterbatasan biaya penelitian.

Media wayang yang akan dikembangkan bertujuan untuk mempermudah guru dalam penyampaian konsep materi pembelajaran yang berkaitan dengan materi tokoh pahlawan nasional kepada peserta didik khususnya tokoh Sultan Hasanuddin dan Sultan Agung Hanyokrokusumo. Manfaat penggunaan wayang adalah penyampai pesan moral pada beberapa tokoh pahlawan yang dipelajari kepada peserta didik. Media dapat meningktkan dikap positif peserta didik dalam proses pembelajaran (Karo-Karo \& Rohani, 2018). Terbentuknya media wayang membuat peserta didik menjadi dinamis dalam siklus pembelajaran, karena mereka bermain serta belajar bersama untuk memahami peran tokoh masyarakat yang sedang diteliti. Wayang dapat dimanfaatkan sebagai hubungan sosiokultural aspek budaya (Widianto, 2017). Materi pembelajaran peran tokoh pahlawan nasional terdapat pada pembelajaran tematik kurikulum tahun 2013 pada kelas IV SD, khususnya pada muatan IPS, Tema 5 Pahlawanku, Sub Tema 2 Pahlawanku Kebanggaanku, pada Pembelajaran 1. Kompetensi inti dan juga kompetensi dasar dijadikan peneliti sebagai semacam perspektif dalam pembuatan RPP dan silabus pembelajaran, sebagai salah satu instrumen pendukung dalam penilaian validasi materi. Khususnya pada validasi materi peran tokoh pahlawan nasional.

Berdasarkan gambaran di atas, diyakini bahwa penelitian ini juga bisa bermanfaat bagi peserta didik bisa menguasai topik muatan pelajaran melalui media yang atraktif tentang peran tokoh pahlawan nasional serta dapat menjadikan peserta didik menjadi dinamis pada tahapan proses kegiatan pembelajaran. Guru dipercaya dapat memanfaatkan media wayang yang bertumpu pada tokoh-tokoh legenda publik sebagai media pilihan dalam mengenalkan tokoh-tokoh masyarakat Indonesia dengan para siswa dan eksplorasi ini dapat dimanfaatkan sebagai tulisan untuk sumber literasi.

\section{METODE}

Pengembangan media wayang terapkan penelitian pengembangan dengan model $R \& D$ (research and development). Strategi penelitian\&pengembangan adalah teknik pengujian yang mampu membuat dan menyampaikan serta menyetujui item yang 
digunakan untuk tujuan instruktif (Sugiyono, 2008). Validator media dan validator materi sejumlah dua pakar yakni wali kelas IV dan kepala sekolah dari UPT SD Negeri 40 Gresik yang bertempat di Jl. Raya Manyar No. 143 Desa Manyar Sidomukti, Kecamatan Manyar, Kabupaten Gresik. Penelitian pengembangan Model $R \& D$ terdapat sepeuluh fase ialah yang pertama potensi dan masalah; yang kedua pengumpulan data; yang ketiga desain produk; yang keempat validasi desain; kelima revisi desain produk; keenam uji coba produk; ketujuh revisi produk; kedepalan uji coba pemakaian produk; kesembilan revisi produk; dan kesepuluh produksi masal. Namun karena adanya kondisi pandemi covid-19 saat ini yang mengalihkan pembelajaran di rumah saja atau school from home sehingga peserta didik tidak lagi belajar disekolah. Berdasarkan hal tersebut peneliti membatasi tahap penelitian hanya pada tahap kelima atau revisi desain, karena kondisi yang ada. Selanjutnya keterbatasan waktu dserta biaya yang menjadi pertimbangan.

Dengan demikian prosedur penelitian dan pengembangan media wayang berbasis tokoh pahlawan nasional ini terdiri dari potensi juga masalah, pengumpulan data, desain suatu produk, validasi desain produk dan revisi desain produk. (1) Potensi Masalah, tahap ini untuk menganalisis kebutuhan yang diperlukan untuk mengembangkan media wayang tokoh pahlawan nasional. Peneliti melaksanakan interviu dengan wali kelas IV Innama, S.Pd. dan diperoleh beberapa masalah yang terjadi dalam tahapan belajar mengajar pada kelas IV UPT SD Negeri 40 Gresik ialah pemahaman materi tokoh pahlawan nasional pada peserta didik masih minim dikarenakan materi sulit dipahami peserta didik terbukti dari kemampuan menarasikan tentang tokoh pahlawan hanya mengetahui nama tokoh belum mengetahui sejarah, peran tokoh dalam perjuangan, dan konsep tentang tokoh yang diberikan oleh guru; kurangnya ketertarikan peserta didik terhadap materi tokoh pahlawan nasional terbukti dari tingkat konsentrasi peserta didik hanya sepuluh sampai lima belas menit awal kegiatan pembelajaran; media pembelajaran yang digunakan di kelas IV masih sederhana yaitu gambar tokoh pahlawan nasional. Sehingga dapat diketahui potensi bahwa peneliti akan mengembangkan media wayang tokoh pahlawan nasional. (2) Pengumpulan Data, tahap ini adalah pengumpulan kebutuhan dilakukan dengan interviu dengan wali kelas IV Innama, S.Pd.; identifikasi materi pada penelitian ini adalah tema 5. Pahlawanku dengan Subtema 2. Pahlawanku Kebanggaanku serta Pembelajaran 1 pada muatan topik pelajaran IPS; mengumpulkan sumber yang relevan; dan melakukan studi literatur. (3) Desain Produk, tahap ini meliputi tahap perencanaan dan pengembangan media wayang tokoh pahlawan nasional yang meliputi menyiapkan alat dan bahan; menyiapkan gambar dari internet; membuat pola gambar; membuat desain awal pada karton; memberi warna; menyatukan rangkaian tubuh wayang; memasang bambu pada wayang; melakukan finishing dengan varnish .. (4) Validasi Desain, setelah dibuat desain media wayang yang dikembangkan maka dibuatlah instrumen pengumpulan data yaitu lembar validasi. Tahap validasi dilakukan untuk memperoleh penilaian dari validator media terhadap media yang sudah dibuat. Selanjutnya validasi materi oleh pakar validasi materi untuk memberikan nilai materi pada media sesuai ketentuan peneliti. (5) Revisi Desain, pada tahap ini diperoleh beberapa komentar dan anjuran untuk perbaikan dari pakar validator selaku pijakan peneliti dalam menyesuaikan kekurangan yang ada pada media maupun materi.

Teknik pengumpulan data pada penelitian ini ialah validasi validasi pakar media dan validasi pakar materi dari UPT SD Negeri 40 Gresik. Validasi ditujukan untuk menilai kelayakan media dan materi oleh validator. Lembar validasi media serta lembar 
validasi materi digunakan sebagai intstrumen penelitian. Skor penilaian validasi yang digunakan mengacu pada skala likert (Arifin, 2013) berikut.

Tabel 1. Skala Likert

\begin{tabular}{ll}
\hline Skor & Kategori \\
\hline 1 & Tidak Baik \\
2 & Kurang Baik \\
3 & Cukup Baik \\
4 & Baik \\
5 & Sangat Baik \\
\hline
\end{tabular}

Langkah analisis data dilaksanakan sebagai berikut.

1. Peneliti menyiapkan data yang diperoleh terlebih dahulu, kemudian melakukan analisis data;

2. Validator menilai media, setelah itu peneliti menghitung skor dari tiap kriteria;

3. Data yang diperoleh dari validator akan dianalisis menggunakan rumus berikut ini.

$$
\text { Nilai Validasi }=\frac{\text { jumlahskorvalidator }}{\text { jumlahskortertinggi }} \times 100 \%
$$

(Riduwan, 2003)

4. Kemudian nilai yang diperoleh dicocokkan dengan interval kevalidan berikut ini. Media yang dikembangkan dapat dikatakan valid apabila mendapatkan nilai dari validator sebesar $\geq 70$.

Tabel 2. Interval Kevalidan Media

\begin{tabular}{ll}
\hline (\%) & \multicolumn{1}{c}{ Tingkat Kevalidan } \\
\hline $76 \%-100 \%$ & Valid \\
$56 \%-76 \%$ & Cukup Valid \\
$40 \%-56 \%$ & Kurang Valid (revisi) \\
$0 \%-40 \%$ & Tidak Valid (revisi) \\
\hline
\end{tabular}

\section{HASIL DAN PEMBAHASAN \\ Hasil}

Proses pengembangan media terdapat lima tahapan diawali dari potensi serta masalah, pengumpulan data, selanjutnya desain suatu produk, kemudian validasi desain, dan juga revisi desain. Berikut adalah penjelasan hasil penelitian.

\section{Potensi Masalah}

Beberapa permasalahan setelah mewawancarai Innama, S.Pd. sebagai wali kelas IV UPT SD Negeri 40 ialah : Materi kurang disukai peserta didik, materi sulit dipahami, dan media pembelajaran yang digunakan belum bervariasi, guru menggunakan gambar dalam penyampaian materi tokoh pahlawan nasional, konsentasi peserta didik yang kurang. Setelah diketahui beberapa permasalah yang terjadi di sekolah, maka peneliti 
menemukan potensi yaitu dengan mengembangkan media wayang berbasis tokoh pahlawan nasional untuk pembelajaran peran tokoh pahlawan nasional.

\section{Pengumpulan Data}

Langkah pengumpulan data yang dilakaukan ialah dengan interviu terhadap wali kelas, menyesuaikan materi kompetensi inti serta kompetensi dasar beserta media pembelajaran wayang tokoh pahlawan. Kemudian dibuatlah RPP dan silabus, hal tersebut bertujuan sebagai acuan penilaian validator pada validasi materi.

\section{Desain Produk}

Desain produk yang dibuat adalah media wayang berbasis tokoh pahlawan. Terdapat dua tokoh pahlawan yang dipilih yaitu Sultan Hasanuddin dan Sultan Agung Hanyokrokusumo. Media ini dibuat dari bahan kertas karton dan beberapa bahan lainnya, dibuat dalam ukuran $40 \mathrm{~cm} \times 30 \mathrm{~cm}$.

Dalam proses pengembangan media wayang tokoh pahlawan nasional terdiri dari beberapa langkah sebagai berikut.

a. Menyiapkan alat bahan

Terdapat beberapa alat dan bahan dalam pembuatan media wayang, meliputi kertas karton, bambu, sedotan, cable tie, air, kuas, cat acrylic, air, gunting, pensil, penghapus, varnish, isolatip.

b. Siapkan gambar tokoh pahlawan nasional dari internet

Berikut ini adalah contoh gambar tokoh pahlawan yang diperoleh dari internet.

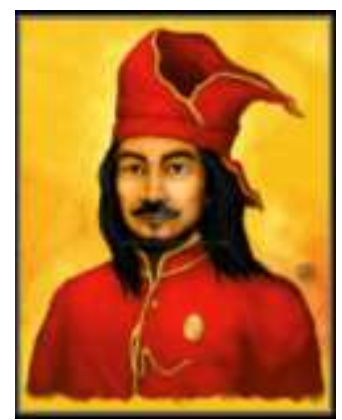

Gambar 4.1 Contoh Gambar Sultan Hasanuddin (http://www.google.com/search?q=gambar+sultan+hasanuddin)

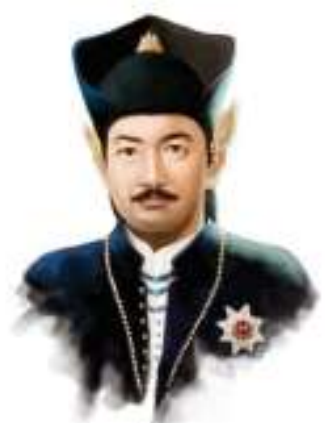

Gambar 4.2 Contoh Gambar Sultan Agung Hanyokrokusumo (http://tribunnewswiki.com/2019/08/06/pahlawan-nasional-sultan-agung)

c. Buatlah pola gambar sesuai contoh yang telah didapat pada karton

Membuat pola gambar media wayang Sultan Hasanuddin dan Sultan Agung pada 
karton dengan menggunakan pensil dan penghapus.

d. Menggunting karton sesuai bentuk pola yang sudah dibuat.

Karton dipotong menyesuaikan pola gambar yang sudah ada.

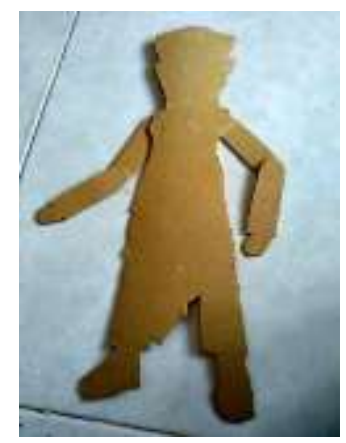

Gambar 4.3 Gambar Pola yang Sudah Dipotong

e. Beri warna karton sesuai pola gambar yang sudah dibuat dengan menggunakan cat acrylic dan kuas.

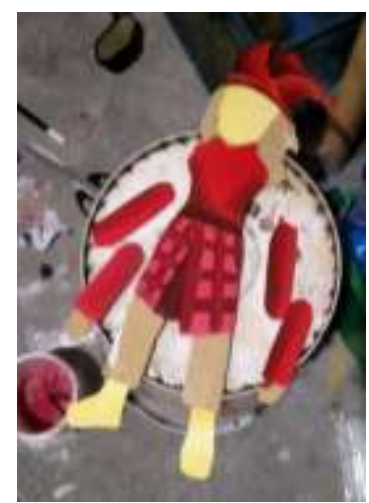

Gambar 4.4 Proses Pembuatan Media Wayang Sultan Hasanuddin

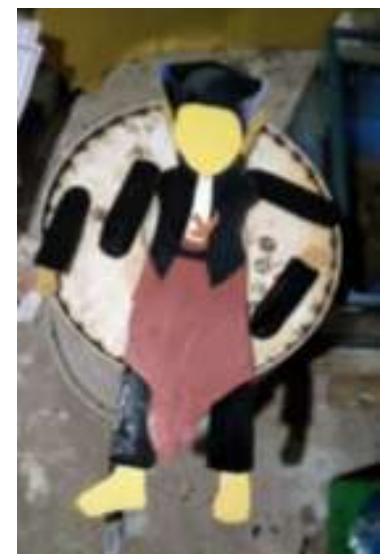

Gambar 4.5 Proses Pembuatan Media Wayang

Sultan Agung Hanyokrokusumo

f. Satukan rangkaian tubuh dan tangan media wayang menggunakan sedotan yang dipanaskan, kemudian dipola agar dapat digerakkan sesuai dengan yang diinginkan. 


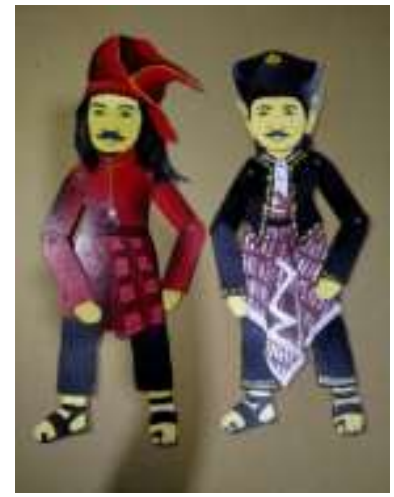

Gambar 4.6 Media Wayang Tokoh Pahlawan Nasional yang Sudah Dirangkai

g. Pasang sebuah kayu atau bambu dibagian belakang media wayang lalu tempelkan isolatip agar kebih kuat.

h. Setelah itu media wayang dilapisi dengan varnish agar warnanya lebih mengkilap dan bertahan lama.

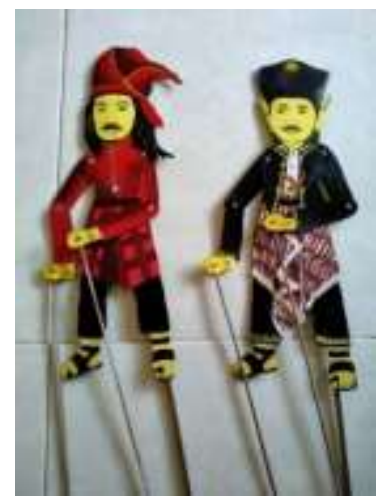

Gambar 4.7 Media Wayang Tokoh Pahlawan Nasional yang Sudah Jadi

\section{Validasi Desain,}

Validasi dilakukan sebagai penilaian kelayakan media dan materi terhadap media. Validasi yang akan dilakukan ada dua, meliputi validasi pakar media terdiri atas dua validator pakar media juga validasi materi terdiri atas dua orang vallidator pakar materi dari UPT SD Negeri 40 Gresik. Pada tahapan ini yang dilakukan peneliti melakukan validasi media juga validasi Materi.

a. Hasil Validasi.

Validasi yang dikerjakan oleh pakar media yaitu guru kelas IV serta kepala sekolah di UPT SD Negeri 40 Gresik sejumlah dua orang. Hal tersebut bertujuan akan diketahuinya penilaian validator atas validitas dan kelaikan media wayang berbasis tokoh pahlawan yang sudah dibuat peneliti. Data validasi yang diperoleh dari validator terlampir pada lampiran 2 dan lampiran 3. Berikut disajikan data hasil validitas yang berasal dari validator pakar media 
Tabel 3. Data Hasil Validitas Ahli Media

\begin{tabular}{|c|c|c|c|}
\hline \multirow[b]{2}{*}{ No. } & \multirow[b]{2}{*}{ Kriteria } & \multicolumn{2}{|c|}{ Skor } \\
\hline & & $\underset{1}{\text { Ahli Media }}$ & $\begin{array}{l}\text { Ahli Media } \\
\quad 2\end{array}$ \\
\hline \multicolumn{4}{|c|}{ A. Kemudahan Dalam Penggunaan } \\
\hline 1. & Media wayang mudah digunakan & 5 & 5 \\
\hline 2. & Media wayang mudah dibuat & 4 & 4 \\
\hline & $\begin{array}{l}\text { Bahan pembuatan media wayang mudah } \\
\text { didapatkan }\end{array}$ & 5 & 5 \\
\hline \multicolumn{4}{|c|}{ B. Kualitas Tampilan } \\
\hline 1. & Tampilan media wayang terlihat menarik & 5 & 5 \\
\hline 2. & Pemilihan warna dalam media tepat & 5 & 4 \\
\hline 3. & Tata letak gambar media wayang rapi & 4 & 5 \\
\hline & $\begin{array}{l}\text { Bentuk media wayang menyerupai sosok } \\
\text { Tokoh Pahlawan Nasional }\end{array}$ & 5 & 4 \\
\hline \multicolumn{4}{|c|}{ C. Memiliki Mutu Dalam Pengolahan Media } \\
\hline & $\begin{array}{l}\text { Media praktis digunakan untuk } \\
\text { pembelajaran }\end{array}$ & 5 & 5 \\
\hline & $\begin{array}{l}\text { Bahan media dapat bertahan dalam } \\
\text { jangka panjang }\end{array}$ & 5 & 4 \\
\hline
\end{tabular}

b. Hasil Validasi Materi

Pakar validasi materi berasal dari guru kelas IV serta kepala sekolah dari UPT SD Negeri 40 Gresik sejumlah dua orang. Tujuan validasi materi ialah mengetahui validitas dan kelaikan isi materi dalam media wayang berbasis tokoh pahlawan yang sudah dibuat oleh peneliti. Berikut ini ialah data validasi oleh validator pakar materi. Hasil validasi yag diperoleh masing-masing validator materi terdapat pada lampiran 6 dan lampiran 7.

Tabel 4. Data Hasil Validitas pakar Materi

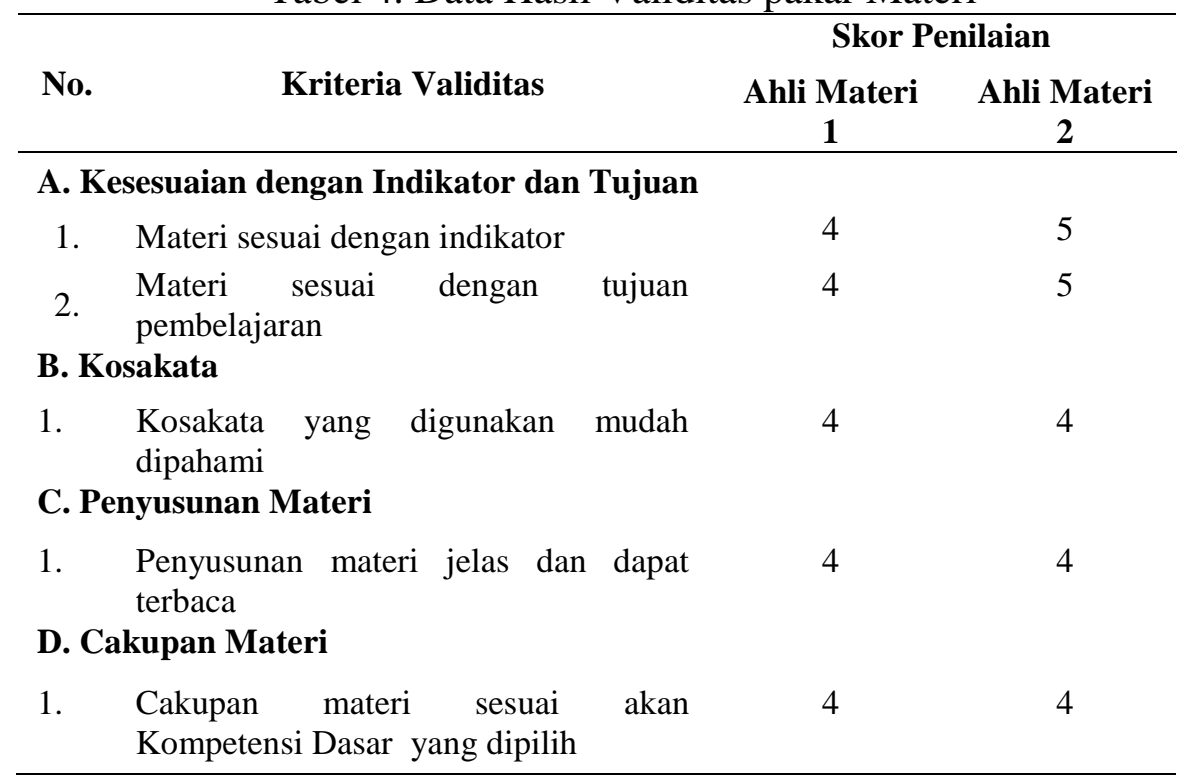

\section{Revisi Desain}

Setelah dilakukan validasi maka diperoleh hasil penghitungan dari pakar validasi media dan pakar validasi materi. Tujuan revisi adalah memperbaiki media jika ada masukan dari validator untuk menghasilkan media yang baik sesuai tujuan penelitian dan 
proses embelajaran (Kurniawan et al., 2018). Selain itu pula didapatkan kritik serta saran pembetulan dari validator untuk peneliti, salah satunya adalah dari validator materi agar peneliti memperbaiki beberapa pemilihan kata yang digunakan dalam materi yang sudah disajikan supaya lebih mudah dipahami peserta didik.

Tabel 3. Data Refleksi Validator

\begin{tabular}{|c|c|c|}
\hline No. & Refleksi & Perbaikan \\
\hline 1. & $\begin{array}{l}\text { Ahli Media } 1 \\
\text { - } \quad \begin{array}{l}\text { Kreatifitas dalam pembuatan media } \\
\text { sudah baik dan sangat menarik }\end{array}\end{array}$ & $\begin{array}{l}\text { Tidak ada perbaikan karna media } \\
\text { mendapatkan penilaian yang baik dari } \\
\text { validator }\end{array}$ \\
\hline 2. & $\begin{array}{l}\text { Ahli Media } 2 \\
\text { - Tidak ada kritik dan saran dari } \\
\text { validator }\end{array}$ & $\begin{array}{l}\text { Tidak ada perbaikan karna media } \\
\text { mendapatkan penilaian yang baik dari } \\
\text { validator }\end{array}$ \\
\hline 3. & 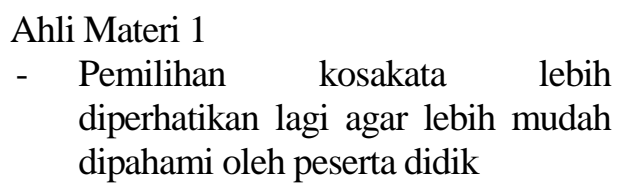 & $\begin{array}{l}\text { Perubahan pilihan kata pada beberapa } \\
\text { kalimat }\end{array}$ \\
\hline 4. & $\begin{array}{l}\text { Ahli Materi } 2 \\
\text { - } \quad \text { Kegiatan belajar mengajar sudah } \\
\text { sesuai dengan indikator dan tujuan } \\
\text { - } \\
\text { Materi sudah sesuai dengan KD }\end{array}$ & $\begin{array}{l}\text { Tidak ada perbaikan karna materi sudah } \\
\text { mendapatkan penilaianyang baik dari } \\
\text { validator }\end{array}$ \\
\hline
\end{tabular}

\section{Pembahasan}

Pengembangan media seagai alat pembelajaran disusun berdasar kebutuhan dan tujuan pembelajaran. Penjabaran hasil penelitian menunjukkan bahwasannya media wayang layak untuk diterapkan dalam tahapan belajar mengajar. Media yang dibuat menunjukkan hasil yang dapat dicapai kemudian media tersebut dapat dimanfaatkan untuk pembelajaran (Asyhari \& Silvia, 2016).

\section{Validasi Media}

Berikut bagan hasil validasi media.

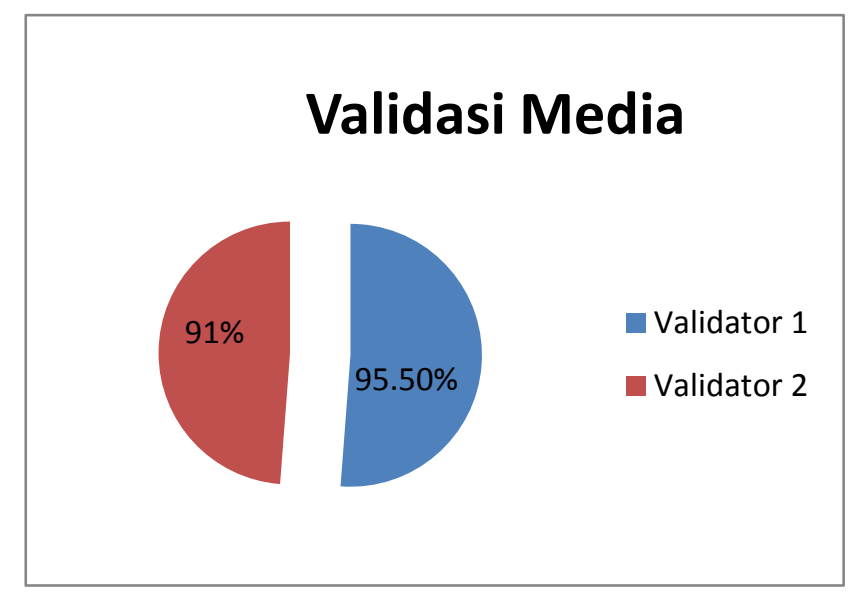

Bagan 1. Hasil Validasi Media

Bagan di atas menunjukkan bahwa penilaian ahli media 1 memberikan nilai validasi sebesar $91 \%$ atau nilai 43 , dengan penilaian pada aspek penilaian media yang 
pertama yakni aspek kemudahan dalam penggunaan dengan indikator penilaian (1) media wayang mudah untuk digunakan, mendapatkan hasil sebesar 5 termasuk kelompok sangat baik yang menunjukkan bahwa media wayang sangat mudah untuk digerakkan saat digunakan; (2) media wayang mudah untuk dibuat, diperoleh nilai 4 termasuk kkelompok baik yang menunjukkan bahwa cara pembuatan media wayang mudah untuk dilakukan; (3) bahan pembuatan media wayang mudah didapatkan, didapatkan nilai 5 tergolong dalam sangat baik yang menunjukkan bahwa bahan pembuatan media wayang sangat mudah untuk didapatkan di pasaran.

Aspek penilaian media yang kedua yakni kualitas tampilan dengan indikator penilaian (1) tampilan media wayang terlihat menarik, diperoleh nilai sebanyak 5 termasuk dalam keriteria sangat baik yang menunjukkan bahwa tampilan media wayang terlihat sangat menarik; (2) pemilihan warna dalam media tepat, diperoleh skor sebesar 5 tergolong dalam kategori sangat baik yang menunjukkan bahwa pemilihan perpaduan warna dalam media sangat tepat; (3) tata letak gambar media wayang rapi, memperoleh skor sebesar 4 termasuk kategori baik yang menunjukkan bahwa tata letak gambar pada media wayang terlihat rapi; (4) bentuk media wayang menyerupai sosok tokoh pahlawan nasional, mendapatkan skor 5 (sangat baik) yang menunjukkan bahwa bentuk media wayang sangat menyerupai sosok tokoh pahlawan nasional. Pertunjukan media yang bagus dapat memperluas kekuatan penalaran siswa dalam ukuran pengajaran dan pembelajaran (Wahyudi et al., 2017). Media yang interaktif bisa menjadikan meningkat penguasaan konsep bagi peserta didik (Kurniawati \& Nita, 2018).

Aspek penilaian media yang ketiga yakni memiliki mutu dalam pengelolaan media dengan indikator penilaian (1) media praktis digunakan untuk pembelajaran, mendapatkan skor 5 termasuk golongan sangat baik yang menunjukkan bahwa media sangat praktis digunakan untuk pembelajaran; (2) bahan media dapat bertahan dalam jangka panjang, mendapatkan nilai 5 gologan sangat baik yang menunjukkan bahwa bahan media sangat dapat bertahan dalam waktu jangka panjang. Pengelolaan media yang baik dapat meningkatkan komunikasi serta korelasi peserta didik terhadap tahapan belajar mengajar di kelas (Nurmadiah, 2016).

Penilaian ahli media 2 mendapatkan nilai validasi sebesar 95,5\% atau nilai 41 , dengan penilaian pada aspek penilaian media yang pertama yakni kemudahan dalam penggunaan dengan indikator penilaian (1) media wayang mudah untuk digunakan (skor 5), termasuk kategori sangat baik yang menunjukkan bahwa media wayang sangat mudah untuk digerakkan saat digunakan; (2) media wayang mudah untuk dibuat, yang menunjukkan bahwa cara pembuatan media wayang mudah untuk dilakukan mencapai skor 4; (3) bahan pembuatan media wayang mudah didapatkan, mencapai skor sebanyak 5 termasuk kategori sangat baik yang menunjukkan bahwa bahan pembuatan media wayang sangat mudah untuk didapatkan di pasaran.

Aspek penilaian media kedua yakni kualitas tampilan, dengan indikator penilaian (1) tampilan media wayang terlihat menarik, mencapai skor sebesar 5 termasuk golongan sangat baik yang menunjukkan bahwa tampilan media wayang terlihat sangat menarik; (2) pemilihan warna dalam media tepat, memperoleh skor interval 4 termasuk kategori baik yang menunjukkan bahwa pemilihan perpaduan warna dalam media tepat; (3) tata letak gambar media wayang rapi, mencapai skor dengan interval 5 termasuk kategori sangat baik yang menunjukkan bahwa tata letak gambar pada media wayang terlihat sangat rapi; (4) bentuk media wayang menyerupai sosok tokoh pahlawan nasional, termasuk kategori baik dengan interval 4 yang menunjukkan bahwa bentuk media wayang menyerupai sosok tokoh pahlawan nasional. 
Aspek penilaian media yang ketiga yakni memiliki mutu dalam pengelolaan media dengan indikator penilaian (1) media praktis digunakan untuk pembelajaran, termasuk golongan sangat baik (skor 5) yang menunjukkan bahwa media sangat praktis digunakan untuk pembelajaran; (2) bahan media dapat bertahan dalam jangka panjang, mendapatkan nilai 5 termasuk golongan sangat baik yang menunjukkan bahwa bahan media dapat bertahan dalam waktu jangka panjang. Pembuatan media wayang bertujuan mengenalkan peserta didik dalam budaya dan karakter yang dapat dijadikan contoh oleh peserta didik (Hidayah, 2018). Media yaang interaktif memberikan kenyamanan dan meningkatkan pemahaman peserta didik dalam menggunakan media pembelajaran (Mauludin et al., 2017).

\section{Validasi Materi}

Dalam validasi materi terdapat beberapa aspek yang diperhatikan. Bagian dari nilai materi yang diterapkan oleh peneliti ialah aspek materi meliputi hal kesesuaian indikator dan tujuan, kosa kata, penyusunan materi, dan isi materi (Sadiman, 2018). Terdapat empat indikator penilaian materi dalam validasi ini, dengan setiap indikator memiliki nilai maksimal 5 sehingga nilai total yang diharapkan sebesar 25 poin. Berikut ini bagan hasil validasi materi.

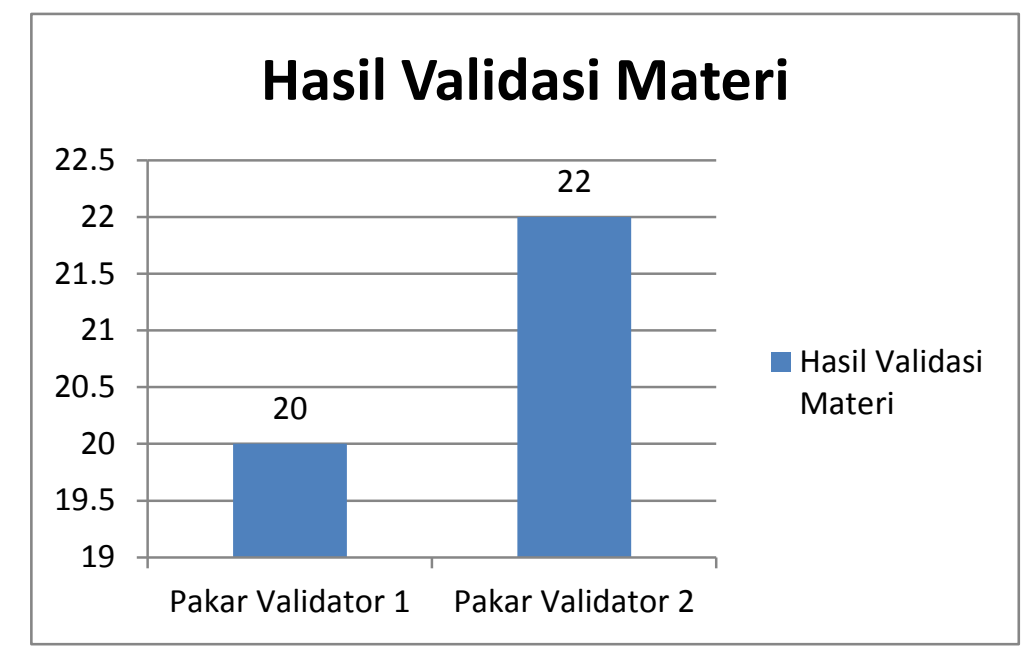

Grafik 1. Hasil Validitas Materi

Berdasar atas grafik tersebut memperlihatkan capaian dari penilaian validasi pakar materi 1 memperoleh skor sebesar 20 poin atau $80 \%$, dengan empat aspek penilaian materi. Aspek pertama yaitu kesesuaian indikator dan tujuan yang mencakup dua indikator penilaian (1) materi sesuai dengan indikator, memperoleh skor sebesar 4 (termasuk kategori baik) menunjukkan bahwa materi sesuai dengan indikator; (2) materi sinkron atas tujuan pembelajaran, diperoleh skor sebesar 4 termasuk kelompok baik yang menunjukkan bahwa materi sesuai dengan tujuan pembelajaran.

Aspek penilaian materi yang kedua yaitu kosakata dengan indikator penilaian (1) kosakata yang digunakan mudah dipahami, memperoleh skor sebesar 4 termasuk kategori baik yang menunjukkan bahwa kosakata yang digunakan mudah dipahami.

Aspek penilaian materi yang ketiga yaitu penyusunan materi dengan indikator penilaian (1) penyusunan materi jelas dan mudah terbaca, memperoleh skor sebesar 4 termasuk kategori baik yang menunjukkan bahwa penyusunan materi jelas dan mudah 
terbaca. Penyampaian materi menggunakan media pembelajaran lebih tersusun dan lebih bermakna (Muhson, 2010).

Aspek penilaian materi yang keempat yaitu isi materi, dengan indikator penilaian (1) isi materi sesuai dengan kompetensi dasar yang dipilih, memperoleh skor sebesar 4 termasuk kategori baik yang menunjukkan kecocokan isi materi dalam media dengan kompetensi dasar.

Penilaian validasi yang diperoleh dari ahli materi 2 sebesar 22 poin atau $88 \%$, dengan empat aspek penilaian materi. Aspek pertama yaitu kesesuaian indikator dan tujuan yang mencakup dua indikator penilaian (1) materi sesuai dengan indikator, mencapai nilai 5 masuk dalam kelompok sangat baik yang menunjukkan bahwa materi sangat sesuai dengan indikator; (2) topik materi sesuai akan tujuan pembelajaran, mencapai skor 5 termasuk kelompok sangat baik yang menunjukkan bahwa materi sangat sesuai dengan tujuan pembelajaran.

Aspek penilaian materi yang kedua yaitu kosakata dengan indikator penilaian (1) kosakata yang digunakan mudah dipahami, memperoleh skor sebesar 4 termasuk kategori baik yang menunjukkan bahwa kosakata yang digunakan mudah dipahami.

Aspek penilaian materi yang ketiga yaitu penyusunan materi dengan indikator penilaian (1) penyusunan materi jelas dan mudah terbaca, memperoleh skor sebesar 4 termasuk kategori baik yang menunjukkan bahwa penyusunan materi jelas dan mudah terbaca. Aspek penilaian materi yang keempat yaitu isi materi, dengan indikator penilaian (1) kandungan materi sesuai akan kompetensi dasar yang dipilih, memperoleh skor sebesar 4 termasuk kategori baik yang menunjukkan bahwa kandungan muatan materi sesuai akan kompetensi dasar yang dipilih.

Dari gambaran hasil serta pembahasan bisa disimpulkan bahwa pengembangan media wayang dinyatakan valid serta layak sebagai salah satu perangkat pembelajaran dalam tahapan kegiatan belajar mengajar. Peneliti tidak melanjutkan ke tahap uji coba karena keadaan pandemi yang tidak memungkinkan.

\section{PENUTUP}

Berikut kesimpulann sesuai dengan penjabaran hasil juga pembahasan.

1. Penelitian juga pengembangan ini dihasilkan dua media wayang tokoh pahlawan nasional yaitu Sultan Hasanuddin dan Sultan Agung Hanyokrokusumo untuk pembelajaran mata pelajaran Tematik muatan IPS pada Tema 5 (Pahlawanku) Subtema 2 (Pahlawanku Kebanggaanku) pada Pembelajaran 1 untuk kelas IV di Sekolah Dasar. Dengan tahapan penelitian yang dilakukan dibatasi hanya lima tahapan saja, ialah potensi juga masalah, tahap kedua pengumpulan data, fase ketiga desain produk, tahap keempat validasi desain, serta tahap kelima revisi desain. Penelitian tersebut tidak melibatkan peserta didik, hal tersebut dilakukan karena disesuaikan dengan adanya kondisi pandemi saat ini.

2. Hasil validasi media memperoleh dua penilaian atas pakar media 1 ialah $95,5 \%$ dan pakar media 2 sebesar 91\%. Penilaian termasuk dalam kategori valid sehingga media wayang dapat dikatakan layak digunakan. Sedangkan untuk hasil validasi materi memperoleh dua penilaian atas pakar materi 1 sebesar $80 \%$, serta pakar materi 2 didapatkan nilai $88 \%$. Penilaian termasuk dalam kategori valid sehingga materi dapat dikatakan layak digunakan.

Ada beberapa gagasan yang perlu disampaikan oleh peneliti ialah (1) media wayang tokoh pahlawan nasional ini dapat dijadikan acuan dalam mengembangkan 
media pembelajaran di kelas guna untuk mempermudah kegiatan belajar mengajar pada peserta didik; (2) Selain itu media wayang dapat juga dikembangkan dengan objek yang lebih bervariasi disesuaikan dengan materi, guna untuk mempermudah penyampaian pada materi pembelajaran yang lain; (3) Media wayang ini dipercaya bisa menjadikan peserta didik bertindak lebih dinamis dalam latihan proses pembelajaran dan semakin efektif menelaah materi tentang pekerjaan para tokoh legenda masyarakat, khususnya pada tokoh Prabu Hasanuddin dan Prabu Agung Hanyokrokusumo; (4) Penelitian berikut bisa dijadikan pijakan untuk penelitian selanjutnya.

\section{DAFTAR PUSTAKA}

Agustina, R., \& Suprianto, D. (2018). Analisis Hasil Pemanfaatan Media Pembelajaran Interaktif Aljabar Logika Dengan User Acceptance Test (UAT). SMATIKA JURNAL. https://doi.org/10.32664/smatika.v8i02.205

Ahlcrona, M. F. (2012). The Puppet's Communicative Potential as a Mediating Tool in Preschool Education. International Journal of Early Childhood. https://doi.org/10.1007/s13158-012-0060-3

Arifin, Z. (2013). Evaluasi Pembelajaran. PT. Remaja Rosdakarya.

Asyhari, A., \& Silvia, H. (2016). Pengembangan Media Pembelajaran Berupa Buletin dalam Bentuk Buku Saku untuk Pembelajran IPA Terpadu. Jurnal Ilmiah Pendidikan Fisika Al-Biruni. https://doi.org/10.24042/jpifalbiruni.v5i1.100

Awalia, I., Pamungkas, A. S., \& Alamsyah, T. P. (2019). Pengembangan Media Pembelajaran Animasi Powtoon pada Mata Pelajaran Matematika di Kelas IV SD. Kreano, Jurnal Matematika Kreatif-Inovatif. https://doi.org/10.15294/kreano.v10i1.18534

Gweon, G., Lee, K. J., Kim, B., Rhim, J., Kim, J., \& Choi, J. (2018). MABLE: Mediating young children's smart media usage with augmented reality. Conference on Human Factors in Computing Systems - Proceedings. https://doi.org/10.1145/3173574.3173587

Hidayah, N. (2018). Upaya Perpustakaan dalam Melestarikan Khazanah Budaya Lokal (Studi Kasus Perpustakaan "HAMKA" SD Muhammadiyah Condongcatur). BIBLIOTIKA : Jurnal Kajian Perpustakaan dan Informasi. https://doi.org/10.17977/um008v2i12018p021

Karo-Karo, I. R., \& Rohani, R. (2018). Manfaat Media dalam Pembelajaran. AXIOM : Jurnal Pendidikan Dan Matematika. https://doi.org/10.30821/axiom.v7i1.1778

Kurniawan, D., Kuswandi, D., \& Husna, A. (2018). Pengembangan Media Video Pembelajaran pada Mata Pelajaran Ipa Tentang Sifat dan Perubahan Wujud Benda Kelas Iv Sdn Merjosari 5 Malang. JINOTEP (Jurnal Inovasi Dan Teknologi Pembelajaran) Kajian Dan Riset Dalam Teknologi Pembelajaran. https://doi.org/10.17977/um031v4i22018p119

Kurniawati, I. D., \& Nita, S.-. (2018). Media Pembelajaran Berbasis Multimedia Interaktif untuk Meningkatkan Pemahaman Konsep Mahasiswa. DoubleClick: Journal of Computer and Information Technology. https://doi.org/10.25273/doubleclick.v1i2.1540

Marsaid. (2016). Islam Dan Kebudayaan: Wayang Sebagai Media Pendidikan Islam Di Nusantara. Kontemplasi: Jurnal Ilmu-Ilmu Ushuluddin.

Masykur, R., Nofrizal, N., \& Syazali, M. (2017). Pengembangan Media Pembelajaran Matematika dengan Macromedia Flash. Al-Jabar: Jurnal Pendidikan Matematika. 
https://doi.org/10.24042/ajpm.v8i2.2014

Mauludin, R., Sukamto, A. S., \& Muhardi, H. (2017). Penerapan Augmented Reality Sebagai Media Pembelajaran Sistem Pencernaan pada Manusia dalam Mata Pelajaran Biologi. Jurnal Edukasi Dan Penelitian Informatika (JEPIN), 3(2), 117123. https://doi.org/10.26418/jp.v3i2.22676

Muhson, A. (2010). Pengembangan Media Pembelajaran Berbasis Teknologi Informasi. Jurnal Pendidikan Akuntansi Indonesia, 8(2). https://doi.org/10.21831/jpai.v8i2.949

Mukholifah, M., Tisngati, U., \& Ardhyantama, V. (2020). Mengembangkan Media Pembelajaran Wayang Karakter pada Pembelajaran Tematik. Jurnal Inovasi Penelitian, 1(4). https://doi.org/10.47492/jip.v1i4.152

Nurmadiah, N. (2016). Media Pendidikan. Al-Afkar : Jurnal Keislaman \& Peradaban, 5(1). https://doi.org/10.28944/afkar.v5i1.109

Nurrita, T. (2018). Pengembangan Media Pembelajaran untuk Meningkatkan Hasil Belajar Siswa. Misykat: Jurnal Ilmu-Ilmu Al-Quran, Hadist, Syari'ah Dan Tarbiyah. https://doi.org/10.33511/misykat.v3n1.171

Riduwan. (2003). Dasar-dasar Statistika. Alfabeta.

Rustad, S., Rahmat, A., Basuki, I., Suyud, Soeprijanto, Asrial, Ridwan, Susilohadi, A., \& Syahril. (2012). Sertifikasi Guru Dalam Jabatan. Direktorat Jendral Perguruan Tinggi Kementerian Pendidikan dan Kebudayaan.

Sadiman, A. S. (2018). Media Pendidikan. PT. Raja Grafindo Persada.

Sani, R. A. (2019). Strategi Belajar Mengajar. PT Raja Grafindo Persada.

Sugiyono. (2008). Metode Penelitian Pendidikan Pendekatan Kuantitatif, Kualitatif, dan $R \& D$. Alfabeta.

Triyanto, E., Anitah, S., \& Suryani, N. (2013). Peran Kepemimpinan Kepala Sekolah dalam Pemanfaatan Media Pembelajaran sebagai Upaya Peningkatan Kualitas Proses Pembelajaran. Jurnal Teknologi Pendidikan.

Wahyudi, U., Wibawanto, H., \& Hardyanto, W. (2017). Pengembangan Media Edukatif Berbasis Augmented Reality untuk Desain Interior dan Eksterior. Innovative Journal of Curriculum and Educational Technology. https://doi.org/10.15294/ijcet.v6i2.19337

Widianto, E. (2017). Media Wayang Mini dalam Pembelajaran Keterampilan Berbicara bagi Pemelajar Bipa a1 universitas ezzitouna tunisia. Kredo : Jurnal Ilmiah Bahasa Dan Sastra. https://doi.org/10.24176/kredo.v1i1.1757

Yasasusastra. (2011). Mengenal Tokoh Pewayangan Biografi, Bentuk, dan Perwatakannya. Pustaka Mahardika.

Yuniati, N., Purnama, B. E., \& Nurgoho, G. K. (2011). Pembuatan Media Pembelajaran Interaktif Ilmu Pengetahuan Alam Pada Sekolah Dasar Negeri Kroyo 1 Sragen. Jurnal Speed - Sentra Penelitian Engineering Dan Edukasi. 